\title{
Analysis of Swimming, Swarming and Twitching Movements of Pseudomonas aeruginosa and its Recombinant Strain
}

\author{
Hüseyin KAHRAMAN ${ }^{1 * \mathbb{D}}$, Duygu ÖZCAN ${ }^{2} \mathbb{D}$ \\ 'İnönü Üniversitesi, Fen Edebiyat Fakültesi, Biyoloji Bölümü, Malatya 44280, Türkiye \\ ${ }^{2}$ İnönü Üniversitesi, Fen Bilimleri Enstitüsü, Biyoloji Bölümü, Malatya 44280, Türkiye
}

Geliş / Received: 24/03/2021, Kabul / Accepted: 03/06/2021

\begin{abstract}
Pseudomonas aeruginosa has several flagella at a single pole. Flagella helps bacteria to settle in solid food. They also perform the swimming movement, which is the movement in the liquid medium, with flagella. In the study, $P$. aeruginosa ATCC 10145 (NRRL B-771) and recombinant $P$. aeruginosa integrated into the chromosome of this bacterium by homologous recombination as a single copy $v g b$ was used. While not observed, it was observed that its recombinant strain also had a pronounced movement of about 2-9 mm. While wild bacteria showed a twitching motion of about $0.2 \mathrm{~mm}$, recombinant bacteria showed a tremor movement of 0.4-0.5 mm. While a small amount of significant swimming movement of approximately $0.2 \mathrm{~mm}$ was observed in wild bacteria, it was observed that there was a much more pronounced movement of 1.1-2.2 $\mathrm{mm}$ in recombinant bacteria. When the sliding motion was examined at the end of the 24-hour period, it was concluded that there was an obvious movement up to 30 times compared to the wild type of the recombinant strain. When the bacteria were examined in terms of the tremor action, it was found that the recombinant strain showed about 2.5 times more shivering movement than the wild type at the end of the 24-hour period. When the bacteria were observed in terms of the swimming test, it was observed that the recombinant strain made approximately 10 times more swimming movements than the wild type at the end of the 24-hour period.
\end{abstract}

Keywords: Pseudomonas aeruginosa, Viteroscilla hemoglobin, Bacterial move

\section{Pseudomonas aeruginosa ve Rekombinant Suşunun Yüzme, Titreme ve Kayma Hareketlerinin Analizi}

$\ddot{O} \mathbf{z}$

Pseudomonas aeruginosa, tek bir kutupta birkaç flagellaya sahiptir. Flagella bakterinin katı besi yerine yerleşmelerine yardımcı olur. Sıvı besi yerindeki hareketleri olan yüzme hareketini de flagella ile gerçekleştirirler. Çalışmada $P$. aeruginosa ATCC 10145 (NRRL B- 771) ve bu bakterinin kromozomuna homolog rekombinasyon ile tek kopya halinde $v g b$ entegre edilmiş rekombinant $P$. aeruginosa kullanılmıştır $P$. aeruginosa'da 0,2-0,3 mm'lik anlamlı belirgin bir kayma hareketi gözlenmezken, onun rekombinant suşun da yaklaşı 2-9 mm arasında belirgin bir hareketin olduğu gözlenmiştir. Yabanıl bakteri yaklaşık 0,2 mm'lik titreme hareketi gösterirken, rekombinant bakteri ise, 0,4-0,5 mm'lik titreme hareketi göstermiştir. Yabanıl bakteride yaklaşık 0,2 mm'lik az miktarda belirgin bir yüzme hareketi gözlenirken, rekombinant bakteride 1,12,2 mm'lik çok daha belirgin bir hareketin olduğu gözlenmiştir. 24 saatlik süre sonunda kayma hareketi incelendiği zaman rekombinant suş yabanıl tipe göre 30 kata varan bariz bir hareketin olduğu sonucuna varılmıştır. Bakteriler titreme hareketi açısından incelendiğinde, 24 saatlik süre sonunda rekombinant suşun

*Corresponding Author: hkahraman71@gmail.com 
yabanıl tipe göre yaklaşık 2,5 kat daha fazla titreme hareketi gösterdiği tespit edilmiştir. Bakteriler yüzme testi açısından gözlendiğinde, 24 saatlik süre sonunda rekombinant suş, yabanıl tipe göre yaklaşık 10 kat fazla yüzme hareketi yaptı̆̆ gözlenmiştir.

Anahtar Kelimeler: Pseudomonas aeruginosa, Viteroscilla hemoglobini, Bakteriyel hareketler

\section{Introduction}

Pseudomonas aeruginosa is a gram-negative, rod-shaped motile bacterium that can survive in the soil, in environments such as marsh and coastal marine habitats, plant and animal tissues. The lengths of these microorganisms are between 0.5-1 $\mu \mathrm{m}$ (width) and 1.5-4 $\mu \mathrm{m}$ (length). The genome size of $P$. aeruginosa is $5.9 \mathrm{Mb}$ with $65 \% \mathrm{G}+\mathrm{C}$ composition (Stover et al., 2000). P. aeruginosa has several flagella at a single pole. Flagella helps bacteria to settle in solid food. They also perform the swimming movement, which is the movement in the liquid food place, with flagella. Pseudomonas piluses belong to the class called type IV. Piluses have an important role in their attachment to epithelial cells and mucosal surfaces. The tip of the pili is responsible for adhering to the host cell surface. Flagellin and pili vary according to their structure, function and genetic organization. In $P$. aeruginosa, the environment perception system plays an important role not only in the production of virulence factors but also in the realization of swimming, trembling and sliding movements. In $P$. aeruginosa, flagella provide the realization of the swimming movement, while the type IV pilus provides the realization of the sliding movement (Semler et al., 1999). The obligate aerobic bacterium Vitreoscilla synthesizes a homodimeric hemoglobin ( $\mathrm{VHb}$ ). Vitreoscilla, which is a subdivision of purple photosynthetic bacteria in the classification, is a sliding member of the Beggiatoaceae family. Although this bacterium is gram-negative obligate aerobes, it tends to grow in oxygen-poor environments (Frey \& Kallio, 2003). Webster et al. In their research in 1986, they determined that hemoglobins are not eukaryotic originated proteins, and that Vitreoscilla stercoraria, a gram-negative bacterium, contains natural hemoglobin. VHb is the best known prokaryotic hemoglobin (Geckil et al., 2001). $\mathrm{VHb}$; It provides a positive effect on productivity and growth in bacteria, fungi, plant and mammalian cells (Lin et al., 2003). The VHb gene increases protein and metabolite synthesis, as well as the growth of bacteria and fungi (Aydin, 2003). Under growth conditions below the oxygen limit, $\mathrm{VHb}$ protein producing cells have higher cell densities and the ability to synthesize more proteins (Demodena et al., 1993). VHb has been shown to have a potential to enhance bioremediation in Pseudomonas (Patel et al., 2008). Within the scope of this study, the movement capacities of $P$. aeruginosa (PaJC) in which the $v g b$ gene was transferred with a transposon-based recombination system and the wild type strain (Pa) without gene transfer were comparatively studied. In this respect, it has been investigated for the first time.

\section{Material and Methods}

\subsection{Microorganism}

In the study, $P$. aeruginosa ATCC 10145 (NRRL B-771) (Pa) and recombinant $P$. aeruginosa (PaJC) integrated into the chromosome of this bacterium as a single copy by homologous recombination were used (Chung et al., 2001). 


\subsection{Motility}

Swarming: $P$. aeruginosa and PaJC to be tested were grown overnight in Luria-Bertani (LB) medium at $30^{\circ} \mathrm{C} .2 \mu \mathrm{l}$ of each culture was added to the petri dishes containing the sliding media previously mentioned. The cultures were incubated at $37^{\circ} \mathrm{C}$ for 16-18 hours (Rashid et al., 2000) and the sliding motion was determined by measuring the diameter of the diffusion from the point of inoculation to the periphery. The gliding action of wild and recombinant strain was compared.

Swimming: For the swimming test, $P$. aeruginosa strains were grown at $37^{\circ} \mathrm{C}$ overnight in LB medium. Petri dishes containing swimming test medium were planted with sterile toothpicks and left to incubate for 16 hours at $25{ }^{\circ} \mathrm{C}$ (Deziel et al., 2001). The swimming motion was determined by measuring the diameter of the turbidity spreading from the planting point towards the periphery.

Twitching: For the shaking test, each of the P. aeruginosa strains to be tested was added with sterile toothpicks to the petri dishes containing shaking test medium and left for 24 hours' incubation at $37^{\circ} \mathrm{C}$. The twitching movement was determined according to the state of the zigzags radiating from the planting point towards the periphery (Deziel et al., 2001).

\section{Resarch Findings}

Swarming: Sliding motion was observed at $30^{\circ} \mathrm{C}$ in P. aeruginosa and PaJC bacteria. While no significant significant sliding motion of 0.2-0.3 $\mathrm{mm}$ was observed in Pa (Figure 1a), a significant movement of approximately $2-9 \mathrm{~mm}$ was observed in PaJC (Figure 1b). The difference was up to 30 times in favor of PaJC.

(a)

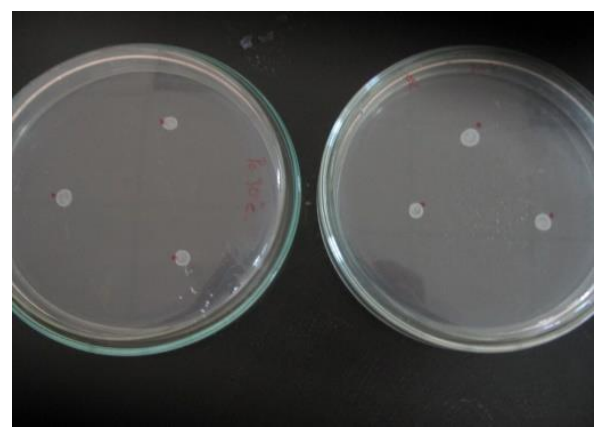

(b)

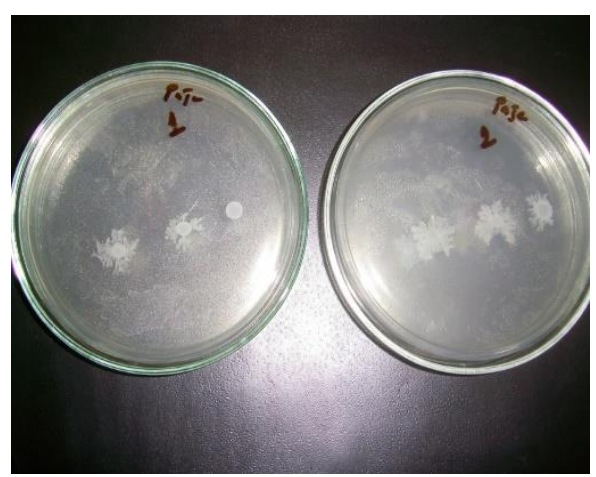


Figure 1. a) sliding motion of $\mathrm{Pa}$ b) sliding motion of PaJC

Twitching: Twitching movement was observed at $37^{\circ} \mathrm{C}$ in P. aeruginosa and PaJC bacteria. While no significant shaking movement was observed in Pa (Figure 2a), it was observed that there was a significant movement in PaJC (Figure 2b). Pa's showed a twitching motion of about $0.2 \mathrm{~mm}$, while PaJC's showed a twitching movement of 0.4-0.5 mm. As a result, 2-2.5 times PaJC moved more

(a)

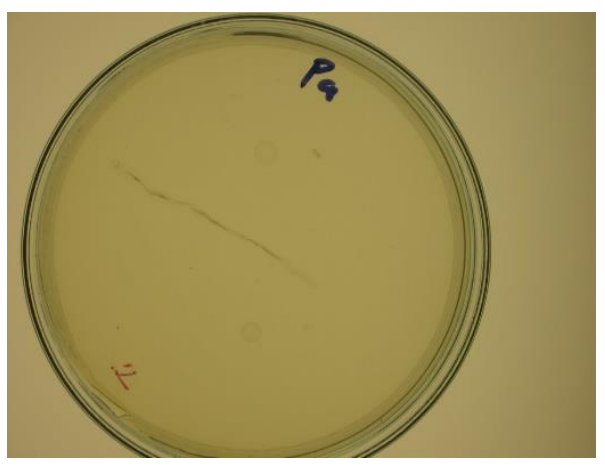

(b)

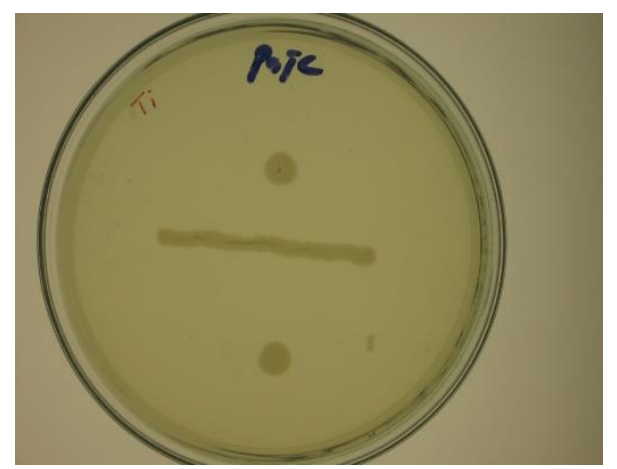

Figure 2. a) The twitching motion of $\mathrm{Pa}$ b) The twitching motion of PaJC

Swimming: Swimming movement was observed at $37^{\circ} \mathrm{C}$ in $P$. aeruginosa and PaJC bacteria. While a small amount of significant swimming movement of approximately $0.2 \mathrm{~mm}$ was observed in $\mathrm{Pa}$ (Figure 3a), a much more pronounced movement of 1.1-2.2 mm was observed in PaJC (Figure 3b). The difference was 10 times in favor of PaJC. 
(a)

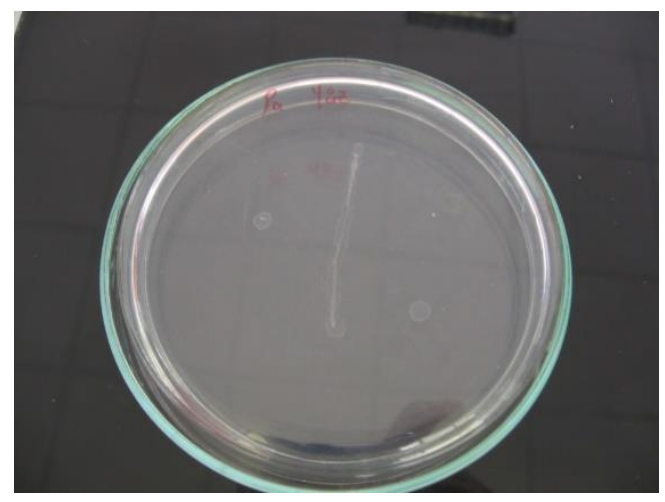

(b)

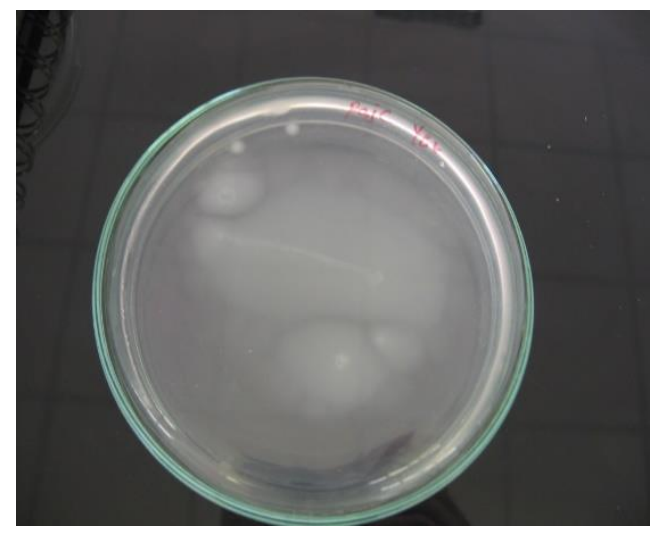

Figure 3. a) Swimming motion of Pa b) Swimming motion of PaJC

\section{Results}

In our study; When the sliding motion was examined at the end of the 24-hour period, it was concluded that the recombinant strain PaJC had an obvious movement up to 30 times compared to the wild type (Figure $1 \mathrm{a}-\mathrm{b}$ ). When the bacteria were examined in terms of the tremor action, it was found that the recombinant strain PaJC showed approximately 2.5 times more tremor than the wild type at the end of the 24-hour period (Figure $2 \mathrm{a}-\mathrm{b}$ ). When the bacteria were observed in terms of swimming test, it was concluded that the recombinant strain PaJC made approximately 10 times more swimming movements compared to the wild type at the end of the 24-hour period (Figure $3 \mathrm{a}-\mathrm{b}$ ). In our study, it was observed that there was a 2-9 mm swarming, 0.4-0.5 mm twitching and 1.1-2.2 $\mathrm{mm}$ swimming movement in the slip test, while Takahashi et al. $P$. aeruginosa PAQ1 strains investigated that there was a significant spread in Davis minimal synthetic agar medium in the presence of $37^{\circ} \mathrm{C}$ oxygen (especially containing $0.8 \%$ sodium citrate and $1.5 \%$ Eiken agar). They concluded that in the presence of $0.1 \%$ sodium citrate there was a $21.9 \pm 1.3 \mathrm{~mm}$ shift, and Luria-Bertani $15.9 \pm 2.7 \mathrm{~mm}$ (Takahashi et al., 2008). According to these results, it was determined that the most active movement was sliding and the $\mathrm{VHb} / \mathrm{vgb}$ system increased all these movements with flagella. Regardless of the resources added to the fattening media, the results of our study coincide with the findings of these studies. As a result, we have not encountered similar studies in the literature, and we think that they will contribute to the literature. 


\section{Acknowledgements}

This work was supported by a Grant (APYB 2010106) from Research Fund Unit of Inonu University.

\section{References}

Aydin, S. (2003). Menadione Knocks Out Vitreoscilla Haemoglobin (VHb): the Current Evidence for the Role of $\mathrm{VHb}$ in Recombinant Escherichia coli. Biotechnology and Applied Biochemistry, 38, 71-76. doi: 10.1042/BA20030046

Chung, J. W., Webster D. A., Pagilla K. R., \& Stark B. C. (2001). Chromosomal Integration of the Vitreoscilla Hemoglobin Gene in Burkholderia and Pseudomonas for the Purpose of Producing Stable Engineered Strains with Enhanced Bioremediating Ability. Journal of Industrial Microbiology \& Biotechnology, 27(1), 27-33.

Deziel, E., Comeau, Y., \& Villemur, R. (2001). Initiation of Biofilm Formation by Pseudomonas aeruginosa 57RP Correlates with Emergence of Hyperpiliated and Highly Adherent Phenotypic Variants Deficient in Swimming, Swarming, and Twitching Motilities. Journal of Bacteriology, 183(4), 1195-1204. doi: 10.1128/JB.183.4.1195-1204.2001

Demodena, J. A., Gutierrez, S., Velasco, J., Fernandez, F. J., Fachini, R. A., Galazzo, D. E., \& Martin, J. F. (1993). The Production of Cephalosporin C by Acremonium chrysogenum is Improved by the Intracellular Expression of a Bacterial Hemoglobin. Nature, 11, 926-929.

Frey, A. D., \& Kallio, P.T. (2003). Bacterial Hemoglobins and Flavohemoglobins: Versatile Proteins and their Impact on Microbiology and Biotechnology. FEMS Microbiology Reviews, 27(4), 525-545. doi:10.1016/S0168-6445(03)00056-1

Geckil, H., Stark, B. C., \& Webster, D. A. (2001). Cell Growth and Oxygen Uptake of Escherichia coli and Pseudomonas aeruginosa are Differently Effected by the Genetically Engineered Vitreoscilla Hemoglobin Gene. Journal of Biotechnology, 85(1), 57-66. doi: 10.1016/s0168-1656(00)00384-9.

Lin, J. M., Stark, B. C., \& Webster, D. A. (2003). Effects of Vitreoscilla Hemoglobin on the 2,4-Dinitrotoluene (2,4-DNT) Dioxygenase Activity of Burkholderia and on 2,4-DNT Degradation in Two-Phase Bioreactors. Journal of Industrial Microbiology \& Biotechnology, 30(6), 362-368. doi: 10.1007/s10295-003-0054-0

Patel, S. M., Stark, B. C., Hwang, K., Dikshit, K. L., \& Webster, D. A. (2008). Cloning and Expression of Vitreoscilla Hemoglobin Gene in Burkholderia sp Strain DNT for Enhancement of 2,4-Dinitrotoluene Degradation. Biotechnology Progres, 16(1), 26-30. doi: $10.1021 / \mathrm{bp} 9901421$

Rashid, M. H., Rao, N. N., \& Kornberg, A. (2000). Inorganic Polyphosphate is Required for Motility of Bacterial Pathogens. Journal of Bacteriology, 182(1), 225-227. doi: 10.1128/JB.182.1.225-227.2000

Semmler, A. B. T., Whitchurch, C. B., \& Mattick, J. S. (1999). A Re-Examination of twitching motility in Pseudomonas aeruginosa. Microbiology-Uk, 145, 2863-2873. doi: 10.1099/00221287-145-10-2863 
Stover, C. K., Pham, X. Q., Erwin, A. L., Mizoguchi, S. D., Warrener, P., Hickey, M. J., Brinkman, F. S., Hufnagle, W. O., Kowalik, D. J., Lagrou, M., Garber, R. L., Goltry, L., Tolentino, E., Westbrock-Wadman, S., Yuan, Y., Brody, L. L., Coulter, S. N., Folger, K. R., Kas, A., Larbig, K., Lim, R., Smith, K., Spencer, D., Wong, G. K., Wu, Z., Paulsen, I. T., Reizer, J., Saier, M. H., Hancock, R. E., Lory, S., \& Olsonet, M. V. (2000). Complete Genome Sequence of Pseudomonas aeruginosa PAO1, an Opportunistic Pathogen. Nature, 406 (6799), 959-964. doi: 10.1038/35023079

Takahashi, C., Nozawa T., Tanikawa T., Nakagawa Y., Wakita J., Matsushita M., \& Matsuyama, T. (2008). Swarming of Pseudomonas aeruginosa PAO1 without Differentiation into Elongated Hyperflagellates On Hard Agar Minimal Medium. FEMS Microbiology Letters, 280(2), 169-175. doi: 10.1111/j.1574-6968.2007.01057.x 